\title{
TRANSLATING LAW INTO A DICTIONARY. A TERMINOGRAPHIC MODEL
}

\author{
WERONIKA SZEMIŃSKA \\ w.szeminska@gazeta.pl \\ University of Warsaw, Poland
}

\begin{abstract}
The purpose of the paper is to present a model dictionary which could serve as a tool for professional translators of legal texts.

Firstly, the methodological approach which was adopted in order to create the model is delineated. It is based on the combined specialist knowledge of three disciplines, namely terminography, translation studies and law. Subsequently, the notion of the translation dictionary as a separate type of terminological dictionary is presented, with particular emphasis on the unit of translation and translation equivalence. The following part of the paper characterises translation of legal texts and its implications concerning the needs of the translator as well as the role of the dictionary in the translation process. Finally, the paper proposes a model dictionary, constructed according to the methodological rules determined at the beginning and in the light of the conclusions drawn from the following analysis.
\end{abstract}

Key words: legal translation, terminological translation dictionary, dictionary model

\section{Introduction}

If we asked translators who their best friend was, they would probably say it was a web search engine - not a dictionary, as one might expect. T. Piotrowski (1994a: 116-117) explains: bilingual dictionaries do not answer translators' needs concerning equivalent search and choice. Therefore, they are treated as springboards for further search rather than as actual sources.

The aim of this article is to put under discussion a concept of a dictionary, designed to serve as an essential tool in specialist translators' work. The concept is presented in the form of a precise description of a terminographic model which could be used in constructing translation dictionaries of law. In order to design such a model, a method was adopted which could be depicted on a triangle, since the construction requires the combination of three disciplines: translation studies, terminography, that is the science of specialist dictionary making, and law, being the subject of the lexicographic work. 


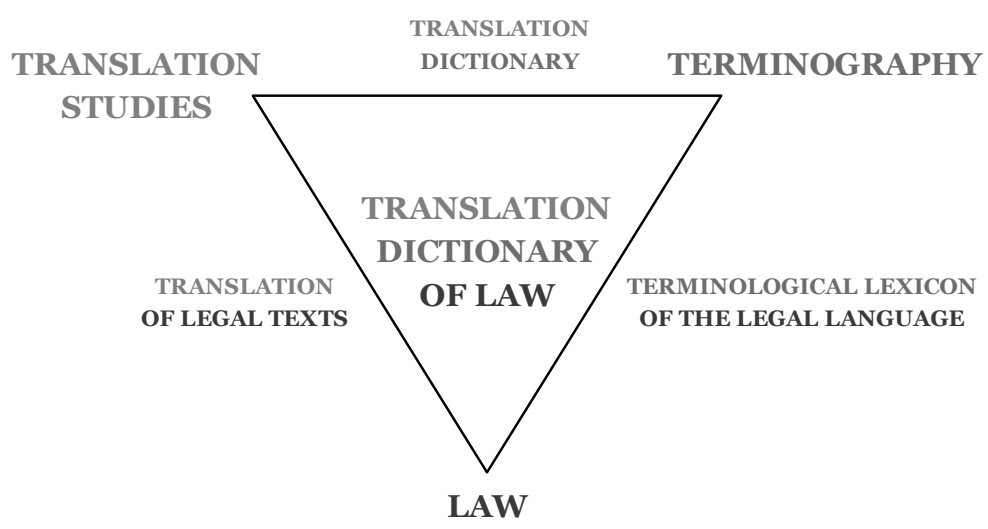

Fig. 1: Relation of the methodologies applied.

More specifically: 1) combining the art and methodology of terminography with the findings of translation studies renders it possible to determine the expectations of a translator towards a translation dictionary and, in consequence, to characterise translation dictionary as a professional translator's tool; 2) projecting the knowledge of law onto the translation studies' findings and methodology is the way to determine the nature of and specific problems in translating legal texts; 3) finally, combining the knowledge of law and the findings of terminography is necessary to analyse the terminological lexicon of the discipline, to learn about the structure of the knowledge in respect of its representation in a dictionary. This combination should render it possible to construct a dictionary which takes account of all the essential aspects: the specific problems in legal translation, the structure of the professional knowledge, and the expectations of a translator towards a translation dictionary.

\section{Terminological Translation Dictionary}

A terminological translation dictionary is a dictionary representing terminology of a particular discipline or branch of knowledge. What is more, it is meant as a tool for professional translators: its purpose is to facilitate the process of translation of specialist texts within this given discipline.

As a terminological dictionary, it cannot be a mere list of terms, but must represent the structure of the terminological lexicon it deals with, thus also allowing the user to gain information about the structure of the knowledge. This can be achieved by various means: on the macrostructural level, that is of the general organisation of the dictionary - the dictionary may for instance take a systematic order or be divided into thematic modules - or on the microstructural level, that is of the organisation of the entry, namely in the way how the conceptual relations are presented in the entry.

As a translation dictionary, it should offer information which would be of particular use to a professional translator. Since what a translator has to understand and subsequently produce, or better to say, reproduce, is a coherent text, the entry should be 
based on textual units as well as provide their translation equivalents. Translation equivalents cannot be established through language analysis according to criteria set in advance, but only through the examination of appropriate texts in the two languages at issue (Piotrowski 1994b: 167; Urbanek 1993: 17-19). While translation equivalence is unstable, always depending on particular texts and contexts as well as the purpose of the translation, the terminographer needs to determine the units of translation a priori, on a certain level of abstraction, unlike a translator working on a given text. It does not suffice, however, to list possible equivalents, but it is necessary to indicate the differences of stylistic, semantic and lexical nature between them. This may be achieved by various means, such as a closed system of indicators, the construction of the entry article or a solution on the macrostructural level.

\section{Legal Translation}

Possibly the majority of legal translators would agree, if only jokingly, with the following statement by P. Chaffey (1997: 69): "As translators we all know deep in our hearts that legal translation is impossible. The very expression legal translation seems to be a contradiction in terms, and yet we do have to translate legislation and legal documents". These words sound radical, but there is much truth in them. Unlike other branches of knowledge, law is not one reality which can be expressed in (more or less) any language, but as many realities as there are legal systems. The language of law, therefore, does not merely describe a given, independent reality. What it primarily does is create the said reality: name and define it, determine the rules which govern it. Legal translation, therefore, is burdened with a particular difficulty, foreign to many other fields of knowledge: it occurs not only between languages, but also between systems, ergo realities. Thus, legal translation involves not only a transition between languages, but also a transition between legal systems. In order to carry out this transition, the translator needs to surmount a twofold incongruence: that of the legal systems and that of the languages, which in turn translates into incongruence on the plane of individual terms.

There are various ways in which a translator deals with the in-congruence. According to the purpose of the translation, he assumes a strategy, which further determines the range of techniques applied. The two opposing strategies are the source system oriented and the target system oriented strategy. In the former one, the differences are emphasised, while the latter has the aim of bringing out the similarities.

The analysis of the process of translating a legal text is a way to distinguish the types of information which a specialist dictionary should include in order to allow the translator to understand the source term, compare the legal systems and find an analogous concept, differentiate between the suggested equivalents and choose an equivalent or a substitute solution, finally to use the chosen expression in a grammatically, lexically and stylistically correct way. The pieces of information the dictionary may need to contain are above all: explanations concerning the meaning and interpretation of the source concept as well as its place in the legal system, data on corresponding concepts in the target legal system, intension and extension of the 
equivalents, suggestions of substitute solutions and rules of use and collocability of the target language expressions.

\section{Dictionary Model}

Terminological dictionary modelling is referred to as terminographic construction and is the most pragmatically oriented part of terminography. The main function of the model presented here is instructional, since the precise description of the model, based on the network of connections between terminography, translation studies and law, ought to become a blueprint for the construction of concrete terminological dictionaries designed for professional translators of legal texts. In other words, on the one hand, the structure of the particular specialist knowledge represented in the dictionary, on the other hand, the needs of the user of the dictionary determine the character of the model, pursuant to which a concrete terminological dictionary is to be created. These relations are presented in the form of the following figure:

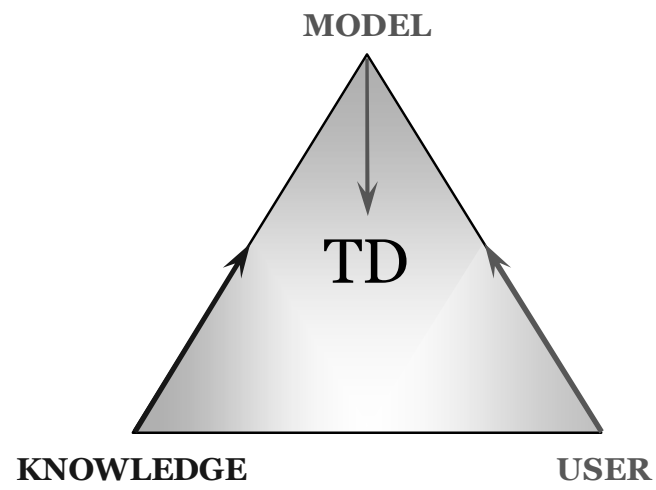

Fig. 2: Outline of the construction of a terminological dictionary (TD).

The general type of the dictionary has been defined as terminological translation dictionary. Due to practical reasons it seems justified to say that every concrete realisation of the proposed model should encompass not the whole of law (whatever that would mean), but the lexicon of a branch of law, for instance only criminal law, or possibly a limited number of connected branches, e.g. criminal law and criminal procedure.

Translation dictionary is by definition a bi- or multilingual work. However, the specificity of law requires a less standard approach, since the translation, or rather the communication occurs between legal systems. Therefore, the dictionary ought not to be defined as bilingual, but as bijural. At this point it is worth reconsidering what branch of knowledge is actually the subject of the work. The translator is not supposed to merely know law, as there is no one law, but to know "laws": legal systems in which the author and the final reader are immersed. What the translator does is compare the said systems, as only the confrontation of the legal reality referred to in the source text with the legal 
reality the receiver of the translation functions in allows the translator to choose an optimal equivalent in accord with the chosen translation strategy. Therefore, it is the result of the said confrontation and comparison which should be reflected in the dictionary; not comparative law perhaps, but the relation of the two legal systems at issue.

This statement is crucial for the design of the dictionary order, since in the case of a terminological translation dictionary it should both be functional from the point of view of the translator and represent the knowledge of the given discipline. In our case, the knowledge should be represented in a way which could facilitate equivalent evaluation and choice, where the vital aspect is the degree of congruence of concepts in the two legal systems. In order to combine these two elements, the following order has been designed. Comparative study of the two legal systems included in the dictionary ought to be carried out and allow the terminographer to divide the concepts and the terms expressing them into three categories: 1) concepts having highly congruent equivalents in the target legal system, 2) concepts having partly congruent equivalents in the target system, and 3) concepts having no congruent equivalents in the target system. The comparative analysis should in particular include the place of the concept in the hierarchy, the scope of application and the legal effects. Vocabulary of each category ought to be placed in a separate module of the dictionary, wherein the entries should be ordered alphabetically. The dictionary may be provided with a diagram reflecting the relation of the modules. The figures below represent two examples of such diagrams, indicating two types of relations reflected in the dictionary:

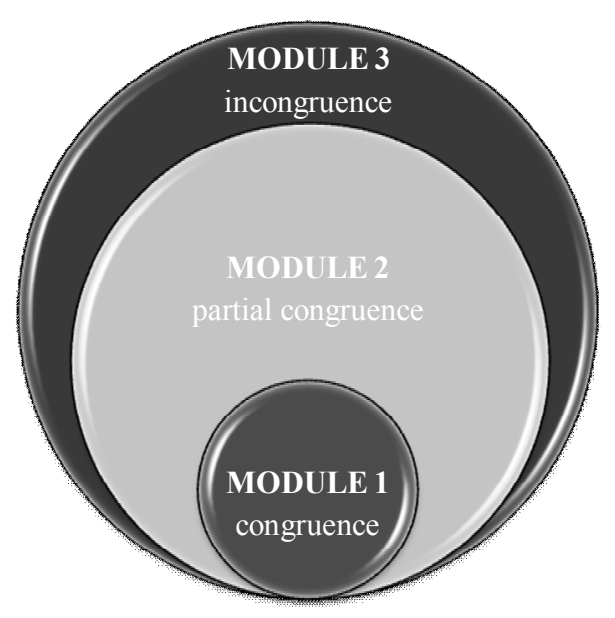

Fig. 3: Diagram of the relations between the dictionary modules (the terms representing concepts with partially congruent equivalents in the target legal system constitute the largest part of the lexicon). 


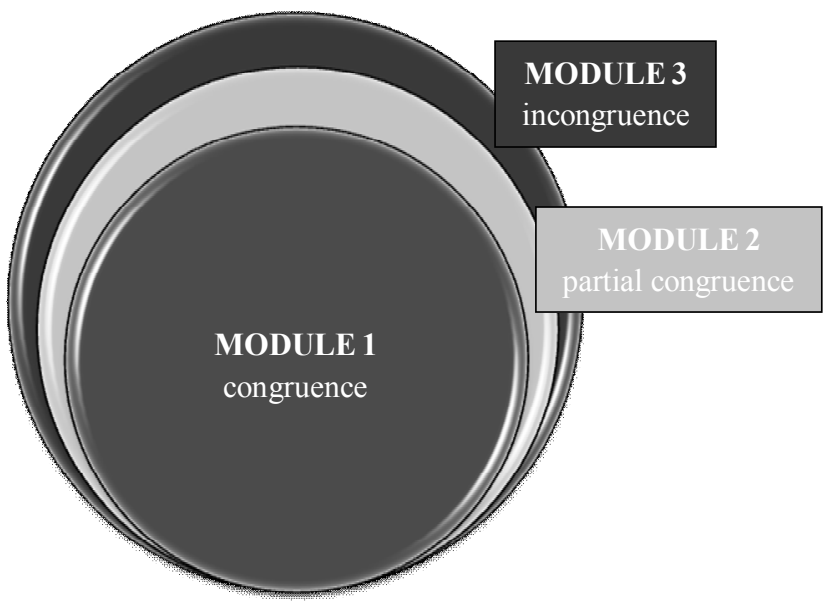

Fig. 4: Diagram of the relations between the dictionary modules (the terms representing concepts with highly congruent equivalents in the target legal system constitute the largest part of the lexicon).

This triple division is limited enough in order not to diminish the functionality of the dictionary, while at the same time it is productive, since it allows the translator to relevantly compare the legal systems. So as to enhance the ease of term search, the dictionary ought to be provided with an index of terms together with references to individual modules. Due to the specificity of legal translation, no a priori rules concerning the mediostructures of the dictionary have been formulated. Regardless of the degree of congruence between the legal systems and individual concepts, the translator always needs to compare the legal systems and may always choose either the source system oriented or the target system oriented strategy, wherefore the information set offered ought to comprise the same elements in all modules.

When it comes to the macrostructure of the dictionary, the work ought to be oriented towards the type of texts whose translation it is to facilitate. Therefore, the corpus should first of all include such texts, followed by the legislative texts in this field (both national and supranational), as well as commentaries and scientific and didactic texts. Chronologically, the corpus should above all comprise texts which are in accordance with the current regulation. Finally, the dictionary ought to include, apart from the modular part and the term index, a description of the metalanguage used, a bibliography, in particular the list of legal texts being the source of terms and explanations, as well as additional elements such as figures, tables and illustrations which may be useful to the translator.

The vocabulary particular to legal texts may be divided into three layers: 1) the vocabulary related to the object of regulation, 2) the vocabulary related to the method of regulation, as well as 3) the vocabulary being the consequence of the normative character of legal texts (Gizbert-Studnicki 2004: 44-45). This division could be stretched out onto all legal documents, that is not only statutes, but also contracts, regulations, deeds, wills etc. (Roszkowski 1999: 8). Legal commentaries and course books are in any case secondary texts based on the primary ones. The vocabulary related to the method of 
regulation and the vocabulary being a consequence of the normative character of legal texts are constituted by strictly legal terminology, whereas the expressions related to the object of regulation gain the quality of legal terms through the said regulation. What follows, the translation of these expressions is subject to the same rules as the translation of typical legal terms. Therefore, the designed dictionary ought to include all three layers of legal vocabulary.

The organisation of the dictionary entry should as fully as possible reflect and answer the needs of the translator of legal texts. The process of term translation begins with the attempt to understand it, that is to determine the semantic scope of the concept represented by the term. In order to offer information allowing the translator to understand and interpret the source term, the entry must include a definition of the term. Since an extensional definition would be impossible to apply for practical reasons, a modified intensional definition could be used, that is one facilitating the comparison of the legal systems involved rather than analysis of the concept in isolation. Such a definition would offer the superordinate as well as the main features distinctive both in relation to coordinates and to corresponding concepts in the target legal system (if such exist). The definitions ought to be formulated on the basis of legislative texts, then judicial texts determining, specifying or modifying the binding interpretation of the concept, finally commentaries and scientific and didactic jurisprudential texts. The definition should be followed by an indication of the source of regulation of the concept, which will direct the translator in their further search, should this be necessary.

If synonyms of a given term exist, they ought to be indicated in the entry and provided with the information on whether they are exact synonyms or contextual synonyms, of broader or narrower meaning. In the situation when a concept regulated in the legislation can be expressed by more terms being exact synonyms (e.g. German Adoption and Annahme als Kind), only the term used in legislation needs to have a full entry.

The other synonyms should also appear in the dictionary as headwords, however not followed by full entries, but only by references to the term used in legislation, where they should be mentioned as synonyms and included in the list of collocations. Such a technique singles out the "legislated" terms from among the synonyms, thus indicating their superordinate place in the lexicon.

The following part of the entry concerns the equivalents. They ought to be divided into four categories:

1) equivalents denoting concepts in the target system which are highly congruent with the source concepts,

2) equivalents denoting concepts in the target system which are partly congruent with the source concepts,

3) source system oriented neologisms, and

4) target system oriented neologisms (e.g. bill of indictment and act of indictment are equivalents of the first and the fourth type, respectively, of the Polish term akt oskarżenia; magistrates' court and minor offences court are equivalents of the second and the third type, respectively, of the term sad grodzki).

It must be noted that the third and the fourth type are understood as neologisms not in the linguistic, but in the legal sense. In other words, they are expressions in the target language which do not denote concepts in the target legal system. The equivalents of the 
first and the second type ought to be followed by definitions and synonyms according to the same rules as the source terms.

The final part of the entry are the collocations of the source term and their translations into the target language. This solution answers the postulate formulated above, namely that a translation dictionary should be based on textual units.

The collocations ought to be ordered according to the grammatical category of the word(s) accompanying the term. If the entry contains a synonym which does not have a separate full entry, the synonym ought to be included in the list of collocations.

Depending on the relations of the languages included in the dictionary, suitable grammatical and phonetic information ought to be provided where relevant; this may be for instance pronunciation, grammatical gender, irregular forms etc. Individual elements of the entry need to be marked by a system of indicators, described in the foreword to the dictionary.

The below figure presents the proposed organisation of the entry:

term [grammatical information] definition (source of regulation) $=$ exact synonym [grammatical information]; $\leq$ contextual synonym with a broader meaning [grammatical information]; $\geq$ contextual synonym with a narrower meaning [grammatical information]

三 equivalent denoting a concept in the target system highly congruent with the source concept [grammatical information] definition $($ source of regulation $)=$ exact synonym [grammatical information]; $\leq$ contextual synonym with a broader meaning [grammatical information]; $\geq$ contextual synonym with a narrower meaning [grammatical information]

$\approx$ equivalent denoting a concept in the target system partly congruent with the source concept [grammatical information] definition (source of regulation) $=$ exact synonym [grammatical information]; $\leq$ contextual synonym with a broader meaning [grammatical information]; $\geq$ contextual synonym with a narrower meaning [grammatical information]

$\mathbf{n}<$ target system oriented neologism [grammatical information]

$=\mathbf{n}$ source system oriented neologism [grammatical information]

- collocation of the term translation of the collocation, translation of the collocation; collocation of the term translation / translation of the collocation

Fig. 5: Organisation of the entry.

\section{Conclusion}

The model presented above is supposed to be a framework, a blueprint for the construction of dictionaries, requiring adjustments to a given pair of languages and legal 
systems. Creating a dictionary according to this model would require the cooperation of a team consisting of terminographers, terminologists, lawyers and scholars specialising in the given branch of law, possibly experts on both legal systems as well as researchers dealing with comparative law. Certainly this would not be an easy task, yet it may be worth the effort if such a dictionary might become a tool of great service to professional translators of legal texts, and render legal translation somewhat less impossible.

\section{References}

Cao, Deborah. 2007. Translating Law. Clevendon - Buffalo - Toronto: Multilingual Matters Ltd.

Chaffey, Patrick Nigel. 1997. "Language, Law and Reality". In On the Practice of Legal and Specialised Translation: Papers from the Third International Forum of Legal and Specialised Translation held in Cracow on 7th and 8th September, 1996, edited by Zofia Rybińska, 69-84. Warsaw: The Polish Society of Economic, Legal, and Court Translators TEPIS.

Gizbert-Studnicki, Tomasz. 2004. "Sytuacyjne uwarunkowanie językowych właściwości tekstów prawnych". In Język - prawo - społeczeństw, edited by Ewa Malinowska, 37-48. Opole: Uniwersytet Opolski.

Groot, Gerard-René de. 1990. „Die relative Äquivalenz juristischer Begriffe und deren Folge für mehrsprachige juristische Wörterbücher". In Translation and Meaning, Part 1. Proceedings of the Maastricht Session of the 1990 Maastricht-Łódz Duo Colloquium on "Translation and Meaning", Held in Maastricht, The Netherlands, 46 January 1990 edited by Marcel Thelen and Barbara Lewandowska-Tomaszczyk, 122-128. Maastricht: Euroterm.

Kielar, Barbara Z. 1977. Language of the Law in the Aspect of Translation. Warszawa: Wydawnictwa Uniwersytetu Warszawskiego.

Kierzkowska, Danuta. 2008. Ttumaczenie prawnicze. ( $3^{\text {rd }}$ edition). Warszawa: Wydawnictwo TEPIS.

Lukszyn, Jerzy, and Wanda Zmarzer. 2006. Teoretyczne podstawy terminologii. $\left(^{\text {nd }}\right.$ edition). Warszawa: Katedra Języków Specjalistycznych.

Pawelec, Monika. 2007. „Zrozumieć prawnika... Słownictwo fachowe z dziedziny prawa w dziełach leksykograficznych". In Współczesny język prawny i prawniczy. Ogólnopolska Konferencja Naukowa 20 kwietnia 2007 r. edited by Adam Niewiadomski, Anna Mróz and Monika Pawelec, 23-32. Warszawa: Wydział Prawa i Administracji, Uniwersytet Warszawski.

Piotrowski, Tadeusz. 1994a. Problems in Bilingual Lexicography. Wrocław: Wydawnictwo Uniwersytetu Wrocławskiego.

—. 1994b. Z zagadnień leksykografii. Warszawa: Wydawnictwo Naukowe PWN.

Roszkowski, Stanisław. 1999. „The Language of the Law as Sublanguage”. In Aspects of Legal Language and Legal Translation edited by Jerzy Tomaszczyk, 7-16. Łódź: Łódź University Press.

Šarčević, Susan. 1997. New Approach to Legal Translation. The Hague-London-Boston: Kluwer Law International. 
Szemińska, Weronika. 2009. Model przekładowego słownika prawa. (M.A. thesis, University of Warsaw).

—. 2009. "Terminologiczny słownik przekładowy: w poszukiwaniu narzędzia doskonałego." In Publikacja jubileuszowa I. Na drodze wiedzy specjalistycznej edited by Marek Łukasik, 112-122. Warszawa: Katedra Języków Specjalistycznych.

Urbanek, Dorota. 1993. Zasady translatorycznego opisu jednostek leksykalnych (na materiale języka rosyjskiego $i$ polskiego). (Doctoral dissertation, University of Warsaw). 